Article

\title{
Comparison of Cassava Starch with Corn as a Feedstock for Bioethanol Production
}

\author{
Sarocha Pradyawong ${ }^{1}$, Ankita Juneja ${ }^{2}$, Muhammad Bilal Sadiq ${ }^{1}{ }^{\circledR}$, Athapol Noomhorm ${ }^{1}$ and \\ Vijay Singh $2, *$ (D) \\ 1 Department of Food Engineering and Bioprocess Technology, Asian Institute of Technology, Pathum Thani \\ 12120, Thailand; sarocha.prad@gmail.com (S.P.); m.bilalsadiq@hotmail.com (M.B.S.); athapol@ait.asia (A.N.) \\ 2 Department of Agricultural and Biological Engineering, University of Illinois at Urbana-Champaign, \\ Urbana, IL 61801, USA; ajuneja@illinois.edu \\ * Correspondence: vsingh@illinois.edu; Tel.: +1-217-333-9510
}

Received: 9 October 2018; Accepted: 10 December 2018; Published: 13 December 2018

check for updates

\begin{abstract}
Cassava is a high potential feedstock for bioethanol production in Asian countries, primarily due to high yield of carbohydrate per unit land, and its ability to grow on marginal lands with minimal agrochemical requirements. The objective of this study was to compare the bioethanol production from cassava starch with corn starch using a conventional and a raw/granular starch hydrolyzing process (GSH). The fermentation performance of cassava starch was compared with three corn starch types with different amylose: Amylopectin ratios. The final ethanol concentration with cassava starch was similar to that of two corn starch types, dent corn and waxy corn for both processes. For the cassava starch, the ethanol concentration achieved with GSH process was $2.8 \%$ higher than that in the conventional process. Cassava starch yielded the highest fermentation rates of the four starches investigated, during the conventional process. Ethanol production and fermentation profiles comparable with corn, a widely used feedstock, makes cassava starch an attractive substrate for bioethanol production.
\end{abstract}

Keywords: bioethanol; corn; cassava starch; granular starch hydrolysis; fermentation

\section{Introduction}

Increased energy consumption and raising environmental concerns have led the world to look for alternative energy sources, especially in the transportation sector. Bioethanol is considered as one of the most promising renewable transportation fuels, and is already blended into gasoline in several countries. The global production of bioethanol in 2017 was estimated as 27.05 billion gallons, with the US contributing about 58\% (15.8 billion gallons) [1]. Since the economics of bioethanol are highly dependent on the feedstock price, there has been an ongoing effort to search for low cost and easily available raw materials [2]. Most of the bioethanol in the United States is produced from corn. However, some countries, particularly in continental Asia, the use of another starch crop, cassava, for energy purposes is encouraged. Cassava or tapioca (Manihot esculenta), is a plant native to South America, with high nutritional value due to its starchy tuberous roots. Global production of cassava is about 281 million tons a year, with Asia contributing about one third of this production [3]. More than half of this global supply is contributed by Africa, where cassava is a primarily used as a food source. Brazil is third largest producer of cassava in the world [3]. One of the major advantages of cassava is its drought-tolerance and capability of growing on marginal soils and degraded lands, and still containing third highest yield of carbohydrate per hectare after sugarcane and sugar beet [4]. The low agro-chemical requirements reduce the energy input for growth of cassava biomass making the use of this crop energy-efficient. Another species of the same genus (Manihot glaziovii) is also considered 
as a bioethanol source for its ability to grow on non-arable lands [5]. Due to high drought and heat tolerance, high yield of starch, and its capability of growing on poor soils without high maintenance, cassava is thus gaining attention as a bioethanol source all over the world.

The conventional method employed for ethanol production from cassava roots usually requires gelatinization of starch followed by liquefaction and saccharification and consequently fermenting the sugars formed with yeast or bacteria [6,7]. Apart from the conventional conversion method, raw starch hydrolysis has also been used for production of ethanol from cassava starch using mixed culture of microorganisms $[8,9]$. Both processes (conventional and raw starch hydrolysis) are used to convert starch to ethanol for both corn and cassava. Since corn is a well-established feedstock for ethanol in the United States [10], it is imperative to know the practical yields of cassava in comparison to corn starch to understand the industrial scale feasibility of cassava as a feedstock for bioethanol production. The cost of cassava ethanol is theoretically estimated as $\$ 0.237 / \mathrm{L}$ [11]. The theoretical ethanol yield $(\mathrm{kg} / \mathrm{ha} /$ year) from cassava has been estimated as three times that of corn [12]. However, there is a lack of studies comparing the ethanol production experimentally from these two ethanol producing starch crops. Bioethanol production from cassava starch has been attempted with various mixed strains of bacteria and yeast $[13,14]$, however, there are limited studies employing process similar to corn dry grind, which is widely used process for bioethanol production in US. Although both cassava and corn share the traits of starchy crops, there are some structural differences in both the starches, which are shown in Table 1, major one being the ratio of amylose to amylopectin. Amylose is a linear chain polysaccharide of glucose molecules connected by $\alpha-1,4$ glycosidic bonds, whereas amylopectin is a water soluble, highly branched polymer, where glucose moelecules are connected with $\alpha-1,4$ glycosidic bonds and the branching takes place with $\alpha-1,6$ glycosidic bonds, occurring every 24 to 630 glucose units (Figure 1). The extraction of corn starch is complex due to the need for steeping to loosen the protein matrices surrounding the starch, whereas cassava starch is easier to extract due to low quantity of proteins and fats in the tuber [15].

Amylose Structure
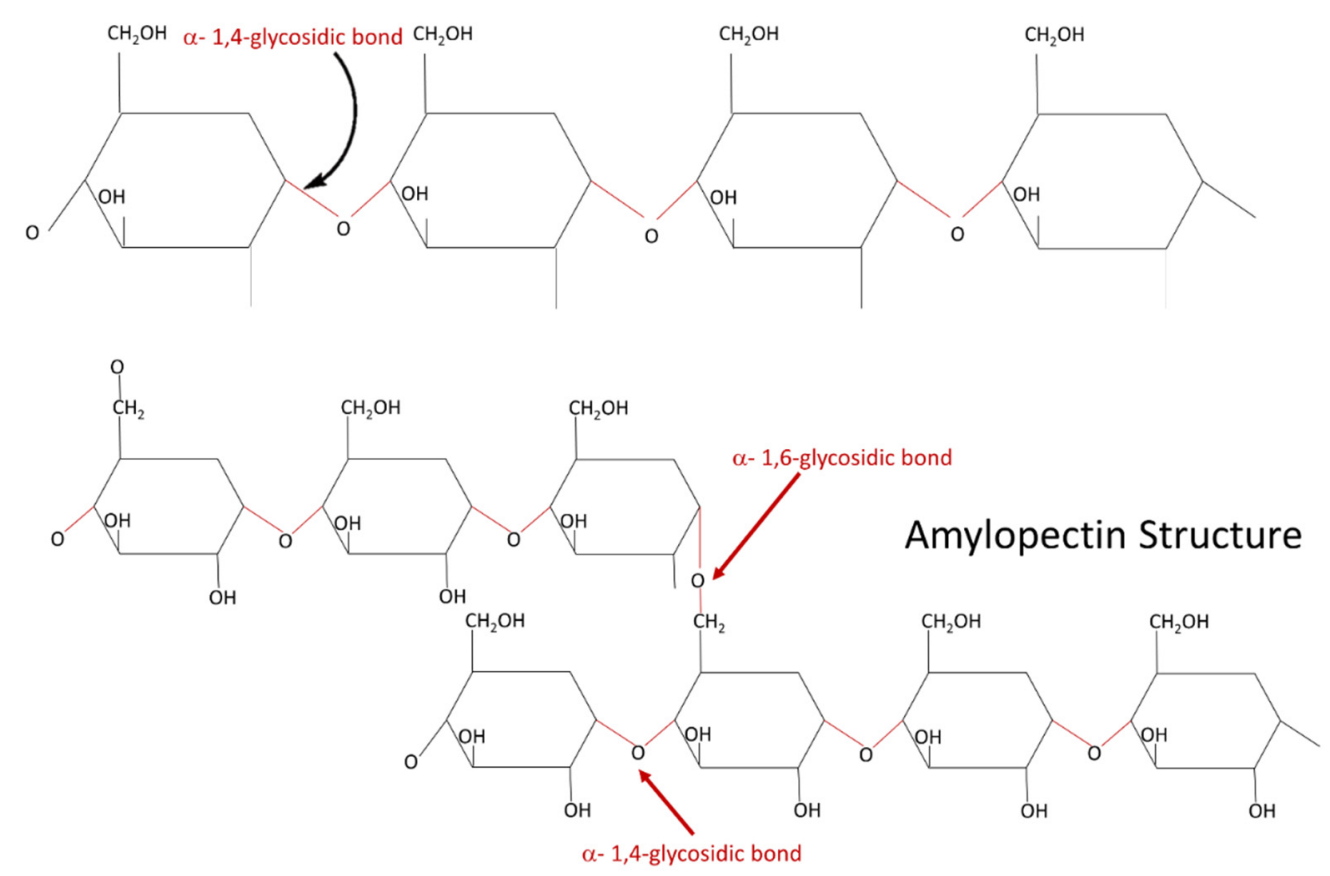

Figure 1. Structures of amylose and amylopectin.

The objective of this study was to compare the fermentation profile and ethanol production of cassava starch with corn starch, using two approaches: the conventional and the granular starch hydrolysis (GSH) process (Figure 2). For a broader comparison, three commercially used corn types 
with different amylose content (dent corn, waxy corn and high amylose corn) were used. Regular dent corn starch contains about 20 to $30 \%$ amylose and 70 to $80 \%$ amylopectin, whereas waxy corn has $<5 \%$ and high amylose corn has $>35 \%$ amylose content [16].

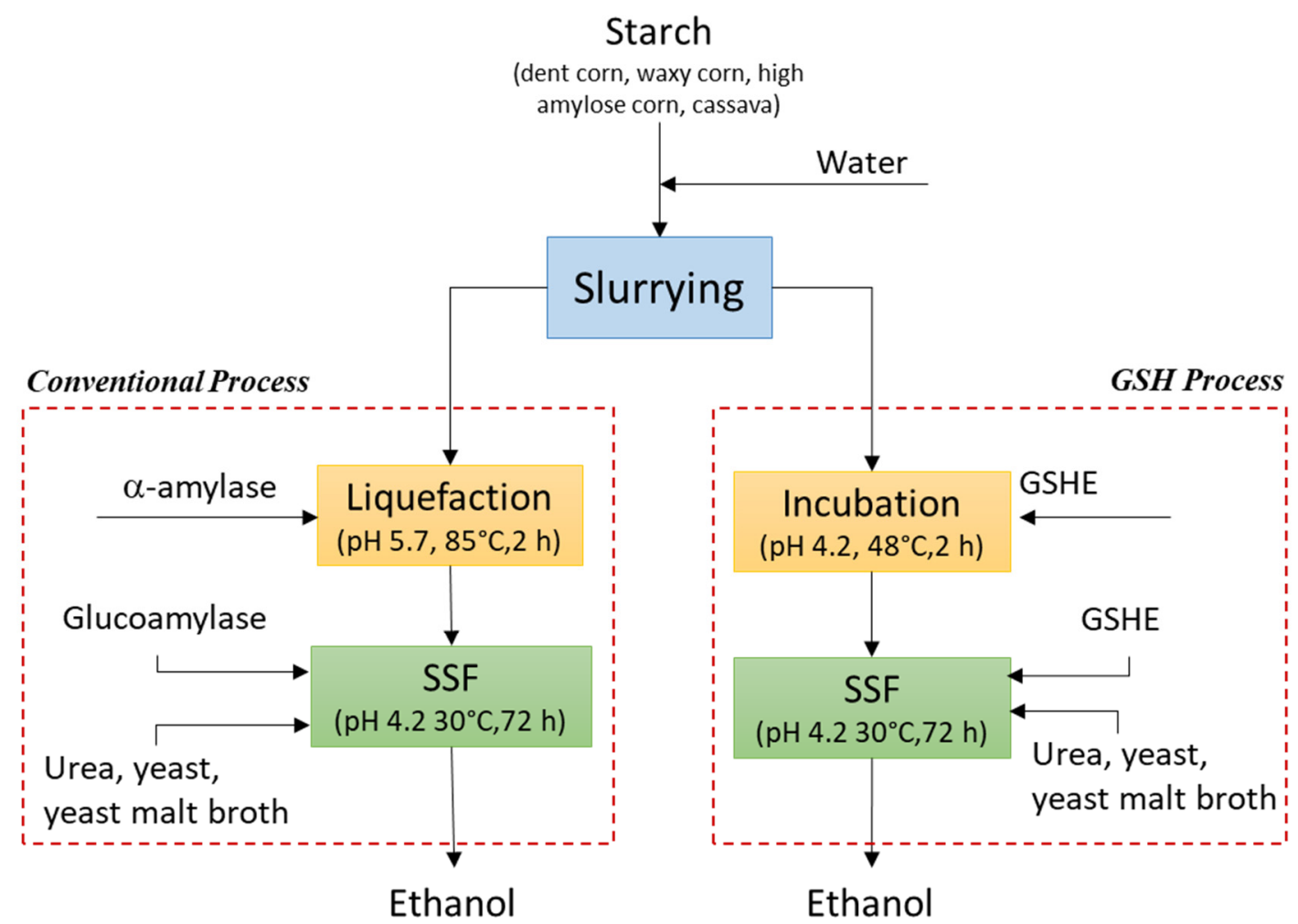

Figure 2. Schematics of the laboratory-scale conventional dry grind and GSH (granular starch hydrolysis) process for ethanol production.

Table 1. Comparison of normal corn starch and cassava starch [17].

\begin{tabular}{ccc}
\hline & Corn Starch & Cassava Starch \\
\hline Content of starch $(\% \mathrm{db})$ & 64 to 78 & 30 to 35 \\
Average granular diameter $(\mu \mathrm{m})$ & 10 & 15 \\
Amylose content $(\%$ of total starch) & 20 to 30 & 17 \\
Degree of polymerization $(\mathrm{DPn})$ & 3000 & 800 \\
Gelatinization temperature range $\left({ }^{\circ} \mathrm{C}\right)$ & 75 to 80 & 65 to 70 \\
\hline
\end{tabular}

\section{Materials and Methods}

\subsection{Materials}

Dent corn starch (Melojel, 30\% amylose), waxy corn starch (Amioca, 1\% amylose), high amylose corn starch (Hylon V, $\sim 65 \%$ amylose) and cassava starch (Novation 3600, Ingredion, Indianapolis, IN, USA) were obtained from Ingredion Incorporated (Westchester, IL, USA). Enzymes, including conventional $\alpha$-amylase (Spezyme ${ }^{\circledR} \mathrm{CL}$, with reported activity of 15,225 AAU/g; AAU: alpha amylase units), conventional glucoamylase (Distillase ${ }^{\circledR}$ SSF, with reported activity of $380 \mathrm{GAU} / \mathrm{g}$; GAU: glucoamylase unit), and GSH enzyme (Stargen ${ }^{\mathrm{TM}} 002$, with an activity of $570 \mathrm{GAU} / \mathrm{g}$; GAU: glycoamylase unit), were provided by DuPont Industrial Biosciences (Palo Alto, CA, USA). Conventional active dry yeast was obtained from the Fermentis-Lesaffre Yeast Corporation (Milwaukee, WI, USA). All starch samples and enzymes were stored at $4{ }^{\circ} \mathrm{C}$ until use. All the chemicals used were of analytical grade and were purchased from Sigma Aldrich (St. Louis, MO, USA). 


\subsection{Conventional Process}

For liquefaction and simultaneous saccharification and fermentation (SSF), a conventional dry grind process as described previously in literature $[18,19]$ was used, with slight modifications (Figure 2). In summary, all four starch ( $30 \mathrm{~g})$ samples were mixed with distilled water to make a slurry with $25 \%$ solids on dry basis. All the experiments were performed in triplicate. The $\mathrm{pH}$ of the slurry was adjusted to 5.7 using $2 \mathrm{~N}$ sulfuric acid, and $10 \mu \mathrm{L}$ of Spezyme ${ }^{\circledR} \mathrm{CL}$ was added for liquefaction. The liquefaction was performed in shaker water bath at $85{ }^{\circ} \mathrm{C}$ for $2 \mathrm{~h}$ with continuous agitation at $100 \mathrm{rpm}$. The liquefied slurry was then transferred in 1-L flask and cooled down to $32{ }^{\circ} \mathrm{C}$ and $\mathrm{pH}$ was adjusted to 4.2 using $2 \mathrm{~N}$ sulfuric acid. Distillase ${ }^{\circledR}$ SSF $(22.56 \mu \mathrm{L})$, urea $(0.4 \mathrm{~g} / 100 \mathrm{~g}$ of starch), yeast malt broth $(4 \mathrm{~g} / 100 \mathrm{~g}$ of starch), and $5 \mathrm{~mL}$ yeast culture $(1.8 \times 108$ cells $/ \mathrm{mL})$ were then added for SSF. Yeast culture was prepared by dispersing $11 \mathrm{~g}$ of active dry yeast and $1 \mathrm{~g}$ yeast malt broth in $89 \mathrm{~mL}$ of distilled water and agitated at $50 \mathrm{rpm}$ and $30^{\circ} \mathrm{C}$ for $20 \mathrm{~min}$. The broth was fermented at $32^{\circ} \mathrm{C}$ for $72 \mathrm{~h}$ with continuous agitation at $100 \mathrm{rpm}$ in shaking water bath. Fermentation was monitored by drawing 1-mL sample from the fermentation slurry at $0,2,4,6,8,20,24,48$, and $72 \mathrm{~h}$ of SSF.

\subsection{Granular Starch Hydrolysis (GSH)}

GSH of starch slurry ( $25 \%$ dry solids content) was carried out by the method previously described in thecliterature [18,19], with slight modifications (Figure 2). To summarize, the $\mathrm{pH}$ of slurry was adjusted to 4.2 by using $2 \mathrm{~N}$ sulfuric acid and $37.7 \mu \mathrm{L}$ StargenTM 002 was added to slurry and temperature was maintained at $48^{\circ} \mathrm{C}$ for $2 \mathrm{~h}$ with continuous agitation at $100 \mathrm{rpm}$. The slurry was then cooled down to $32{ }^{\circ} \mathrm{C}$ followed by $\mathrm{pH}$ adjustment to 4.2 using $2 \mathrm{~N}$ sulfuric acid. StargenTM $002(37.7 \mu \mathrm{L})$, urea $(0.4 \mathrm{~g} / 100 \mathrm{~g}$ of starch), yeast malt broth $(4 \mathrm{~g} / 100 \mathrm{~g}$ of starch), and $5 \mathrm{~mL}$ yeast $(1.8 \times 108$ cells $/ \mathrm{mL})$ were then added to carry out fermentation. Yeast culture was prepared similarly as described above. The broth was fermented at $32{ }^{\circ} \mathrm{C}$ for $72 \mathrm{~h}$ with continuous agitation at $100 \mathrm{rpm}$ in shaking water bath. Fermentation was monitored by drawing 1-mL sample from the fermentation slurry at $0,2,4,6,8,20,24,48$, and $72 \mathrm{~h}$ of SSF.

\subsection{HPLC analysis}

Samples collected during both conventional and GSH process, were centrifuged (model 5415 D, Eppendorf, Westbury, NY, USA) at 11,000 rpm for $3 \mathrm{~min}$. The supernatant was then filtered through $0.2-\mu \mathrm{m}$ syringe filter into $1-\mathrm{mL}$ HPLC vials. The vials were immediately stored at $-20{ }^{\circ} \mathrm{C}$ until analysis. The filtrate was analyzed using HPLC with an ion-exclusion column (Aminex HPX-87H, Bio-Rad, Hercules, CA) and refractive index detector (model 2414, Waters Corporation, Milford, MA, USA). The mobile phase was $0.005 \mathrm{M}$ sulfuric acid at $50{ }^{\circ} \mathrm{C}$ at a flow rate of $0.6 \mathrm{~mL} / \mathrm{min}$. Each sample was analyzed to determine the concentrations of ethanol, glucose, maltose, maltotriose, and glycerol. The HPLC was calibrated with standards and each sample was injected twice for analysis.

\subsection{Fermentation Rates and Ethanol Yields}

Ethanol concentration was measured and was plotted against time. Fermentation rates were calculated during the initial linear phase of fermentation (up to $8 \mathrm{~h}$ ) by calculating the slope of the plot. Starch-to-ethanol conversion efficiencies were calculated as the ratio of actual ethanol yields with the theoretical ethanol yield (Equation (1)):

$$
\eta_{E t O H}=\frac{E_{E t O H}}{E_{T h-E t O H}} \cdot 100
$$

where $E_{T h \_E t O H}$ is theoretical ethanol yield, L/ $\mathrm{kg}$ dry starch; $E_{E t O H}$ is the actual ethanol yield, $\mathrm{L} / \mathrm{kg}$ dry starch. 
Theoretical yields were estimated based on the starch content, assuming complete starch conversion and $100 \%$ fermentation efficiency. Actual ethanol yields were calculated based on methods described elsewhere [20].

\subsection{Statistical Analysis}

Final ethanol concentration and fermentation rate for all four starches was analyzed by analysis of variance (1-way ANOVA) and Fisher's least significant difference (LSD) tests (SAS version 9.4, Cary, NC, USA). The level selected to show the statistical significance in all cases was $5 \%(p<0.05)$. All the experiments were performed in triplicates.

\section{Results}

\subsection{Conventional Dry Grind Process}

The fermentation profiles for all starches during the conventional dry grind process are shown in Figure 3. The final ethanol concentration for dent corn starch $(133.2 \mathrm{~g} / \mathrm{L})$ was the highest among the four starches analyzed. However, statistically there was no significant difference in the final ethanol concentrations of the three starches—dent corn, waxy corn and cassava starch—which indicated the suitability of cassava starch to be used as a comparable starch crop for bioethanol production in Asian countries. The ethanol yield with high amylose corn starch was lower than the other three starches. This was expected due to the high amylose:amylopectin ratio in the high amylose corn starch, which has previously been reported to decrease the ethanol yield [21]. Since amylose is a linear chain polymer, it aligns itself with strong hydrogen bonds, making it difficult for the enzymes to act, resulting in reduced hydrolysis of amylose [21]. High temperatures provided during liquefaction of starches in conventional dry grind process assist in breaking down these hydrogen bonds and make the amylose available to enzymes. The final ethanol produced by cassava $(124.4 \mathrm{~g} / \mathrm{L})$ starch was higher than that reported previously in literature $(\sim 71 \mathrm{~g} / \mathrm{L})$ [22].

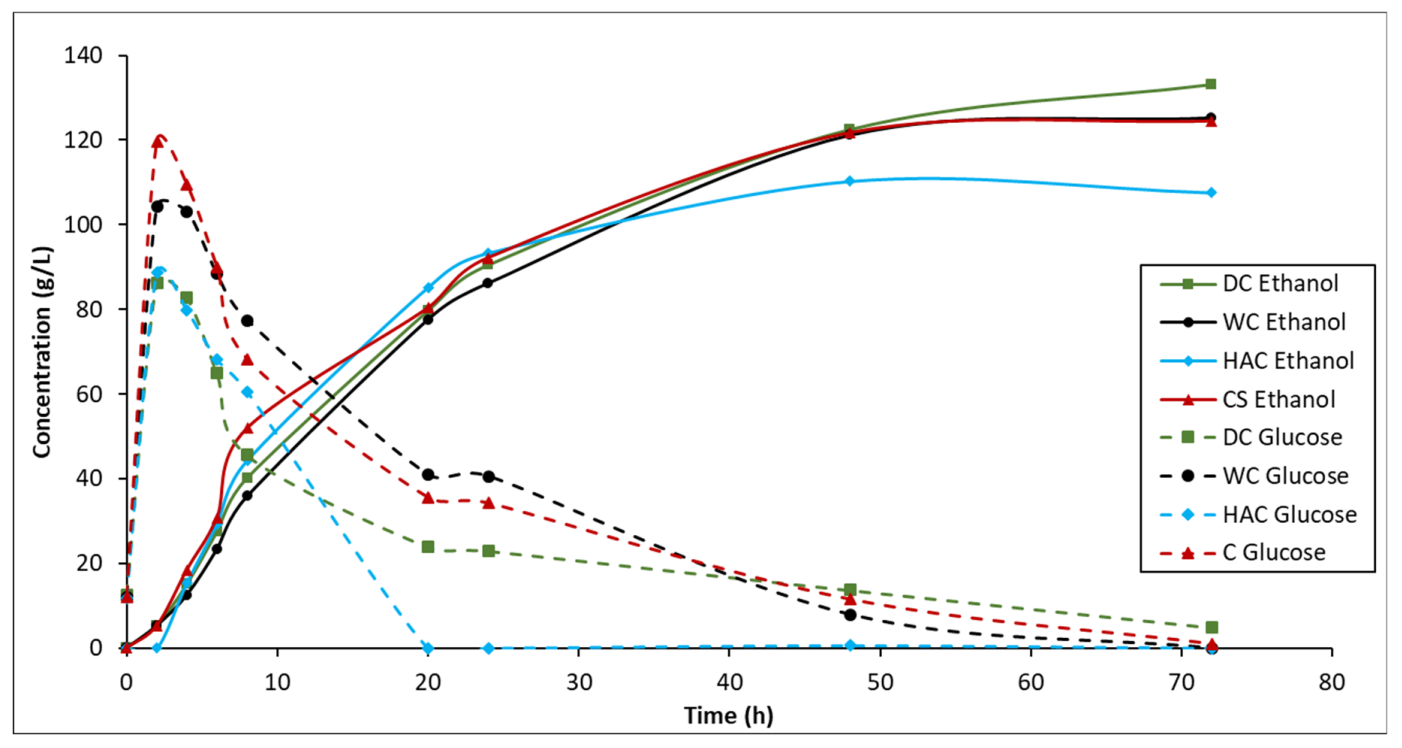

Figure 3. Comparison of ethanol and glucose profiles of dent corn (DC), waxy corn (WC), high amylose corn (HAC), and cassava starch (CS) during conventional fermentation (SSF at $30^{\circ} \mathrm{C}$ for $72 \mathrm{~h}$ with glucoamylase and yeast).

About $5 \mathrm{~g} / \mathrm{L}$ and $1 \mathrm{~g} / \mathrm{L}$, glucose was left unconverted in case of dent corn and cassava, respectively; whereas complete conversion was observed for waxy corn and high amylose corn starch (Figure 3). However, glucose released in the first $8 \mathrm{~h}$ is highest for cassava starch $(119.5 \mathrm{~g} / \mathrm{L})$, indicating better breakdown of starch in to polysaccharides during liquefaction. In contrast, high amylose corn starch 
released least glucose during fermentation, which can be attributed to the inefficient hydrolysis due to high amylose content. Similar trend of low glucose formation with high amylose content was observed in an earlier study [21].

The initial plot of ethanol vs time (up to $8 \mathrm{~h}$ ) provides a linear trend (Figure 4a), slope of which was used to calculate the fermentation rate. All starches for conventional process showed good linear fit for first $8 \mathrm{~h}$ of fermentation. For GSH process, high amylose corn was the only starch that did not fit the linear plot $\left(R^{2}=0.47\right)$, where other fits could be investigated. The fermentation rates of all four starches are shown in Table 2. Highest fermentation rate was observed for cassava starch (0.965), followed by high amylose corn starch (0.931). During the initial hours of fermentation, the fermentation rate of cassava is observed to be statistically higher than that of dent corn. Despite low final ethanol concentration, high fermentation rate for high amylose corn starch can be due to the better functioning of the yeast in presence of low glucose concentrations.

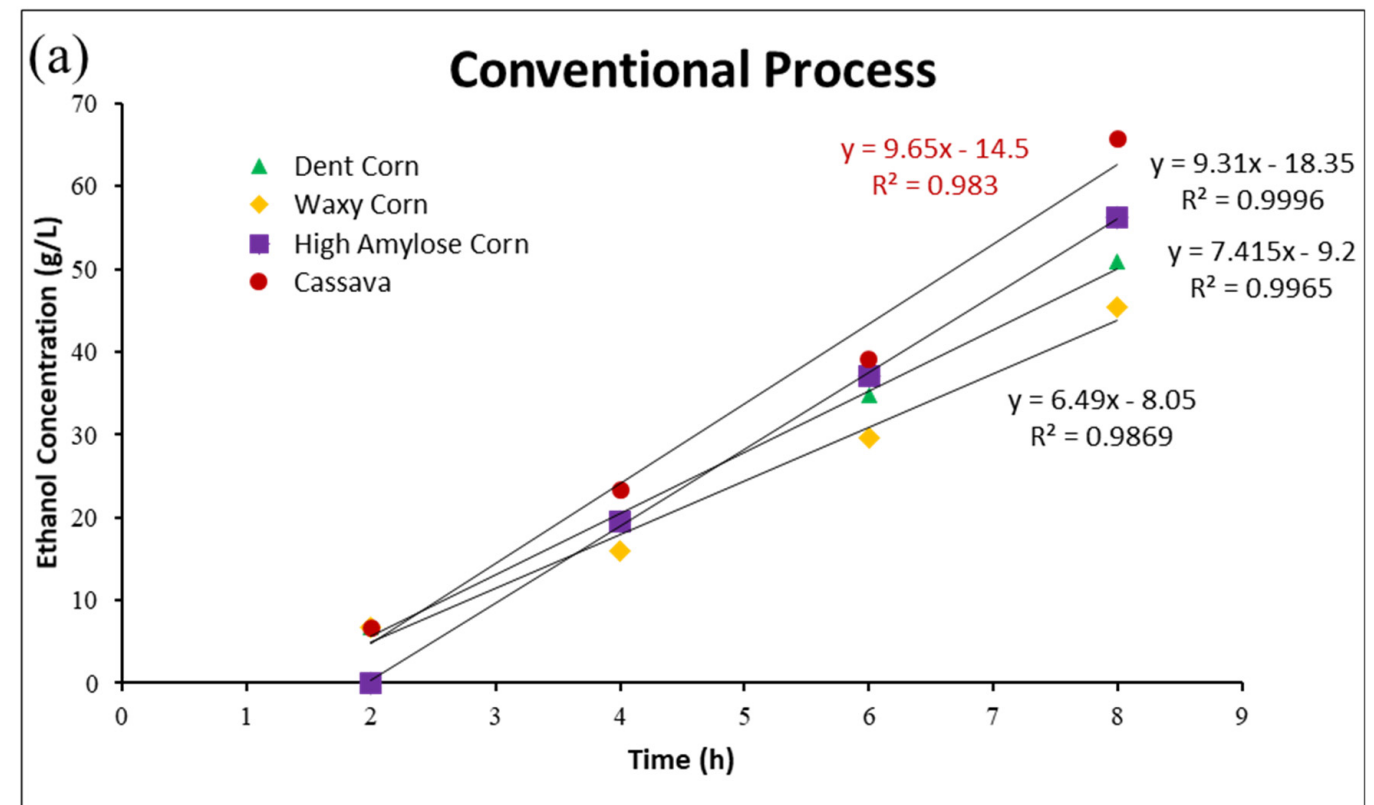

(b)

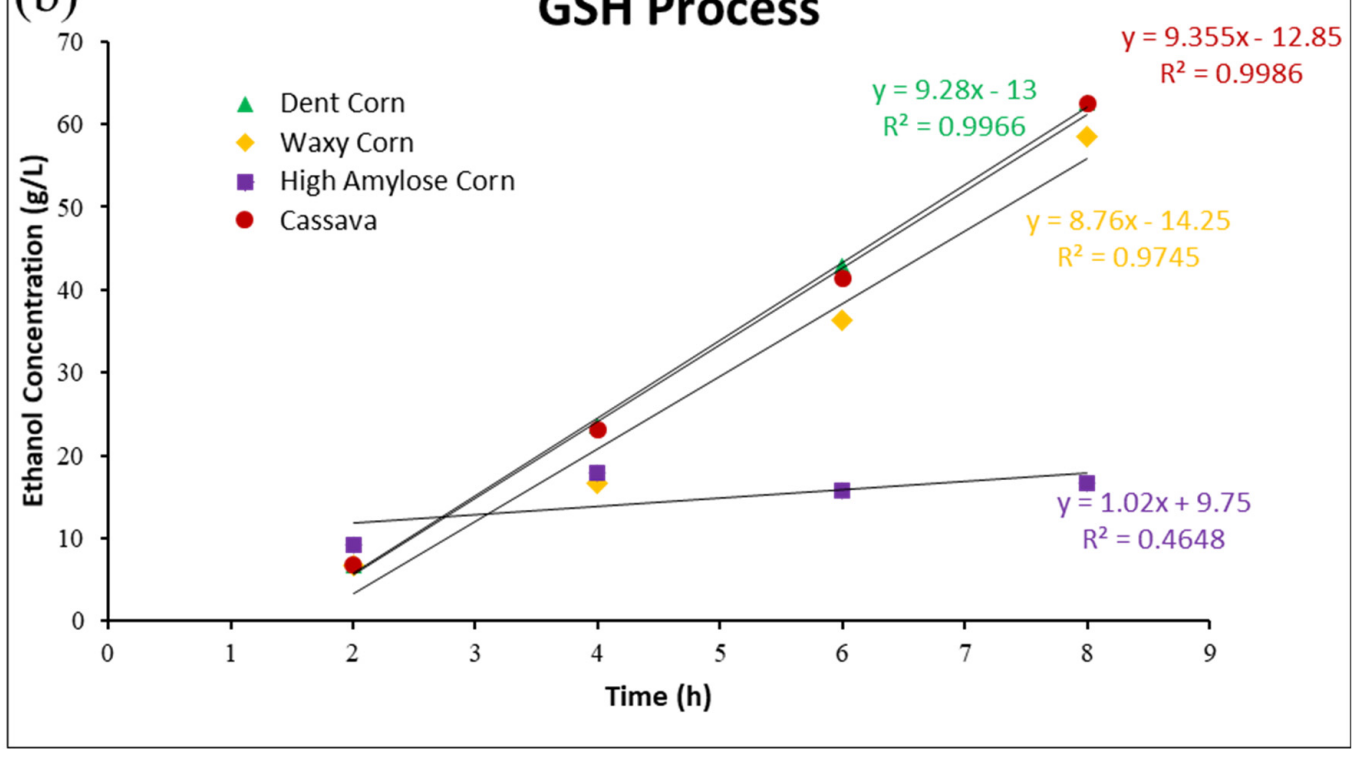

Figure 4. Fermentation rates calculated as slopes of ethanol concentration plotted with time during the first $8 \mathrm{~h}$ of fermentation during (a) conventional and (b) GSH (granular starch hydrolysis) process. 
Table 2. Fermentation rates for ethanol production during the conventional and GSH process.

\begin{tabular}{ccc}
\hline Starch Type & Conventional & GSH \\
\hline Dent corn & $0.7415^{\mathrm{b}}$ & $0.9355^{\mathrm{a}}$ \\
Waxy corn & $0.649^{\mathrm{c}}$ & $0.876^{\mathrm{b}}$ \\
High amylose corn & $0.931^{\mathrm{a}}$ & $0.102^{\mathrm{c}}$ \\
Cassava & $0.965^{\mathrm{a}}$ & $0.928^{\mathrm{a}}$ \\
\hline
\end{tabular}

Similar letters represent statistically similar values at $p<0.05$.

The fermentation efficiencies of starch to ethanol conversion in conventional process ranged from $62.8 \%$ to $81.9 \%$, highest being for dent corn starch and lowest for high amylose corn starch (Figure 5). The efficiency of dent corn starch was higher than previously determined efficiency of dent corn grits (62.4\%) [23]. The fermentation efficiency of cassava starch by conventional method was calculated as $74.5 \%$, which was higher that earlier reported results of $68 \%$ efficiency with Saccharomyces cerevisiae [8], but lower than another reported value of $82.88 \%$ [11]. In case of GSH process, the efficiency of dent corn starch was $74.1 \%$, comparable to previously reported in literature (76.7\%) [23]. The fermentation efficiency of cassava starch was calculated as $77 \%$, which was $3.7 \%$ higher than that with conventional process. Previously reported literature has shown fermentation efficiency of cassava ranging from $82-99 \%$, based on the variety of cassava and microorganism used $[9,11]$.

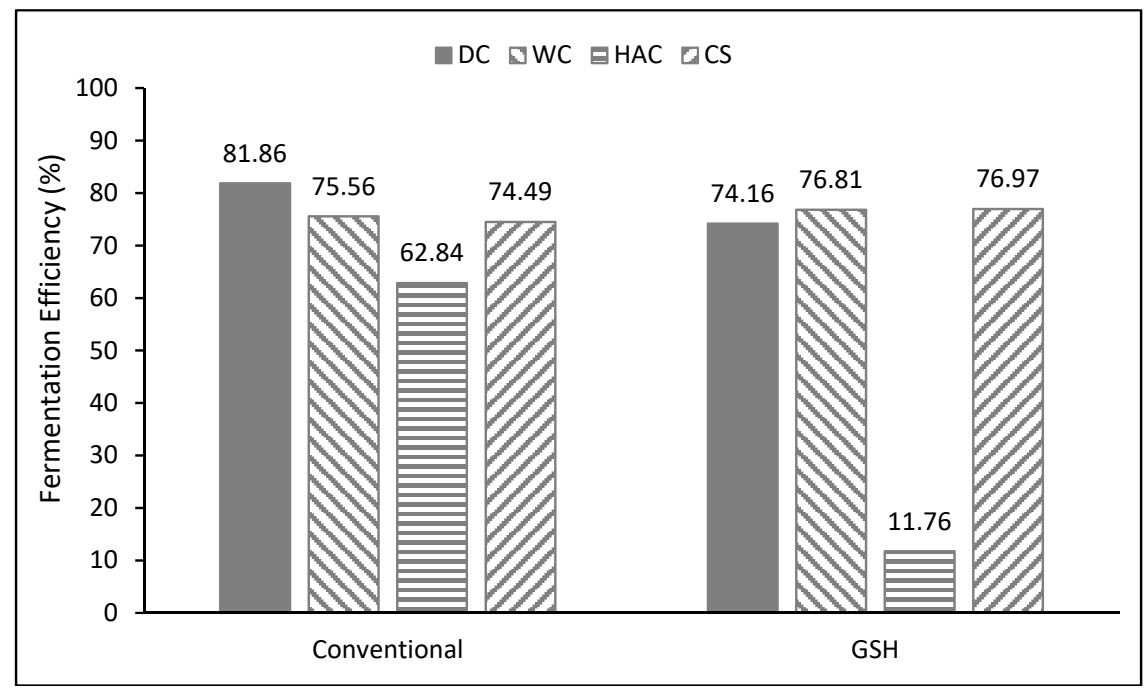

Figure 5. Fermentation efficiencies of four starches (dent corn (DC), waxy corn (WC), high amylase corn (HAC) and cassava starch (CS) with conventional and GSH method.

Concentrations of other sugars and sugar alcohol produced in the conventional process are presented in Table 3. Final glycerol production was highest among all sugars and sugar alcohols for all four starch types. Glycerol formation by Saccharomyces cerevisiae under anaerobic conditions is caused by the need for reoxidation of NADH [24]. Highest glycerol concentration was observed in dent corn $(8.02 \mathrm{~g} / \mathrm{L})$, which was statistically similar to that produced with cassava, whereas waxy corn starch produced the lowest glycerol $(5.30 \mathrm{~g} / \mathrm{L})$. Maltotriose concentration at the beginning of SSF was in range of 22.08-33.94 g/L, similar to maltose concentration, except for high amylose corn starch, where no maltose was detected throughout fermentation. At the end of the fermentation, no maltose was detected for waxy corn starch, and both dent corn and cassava starch had less than $1 \mathrm{~g} / \mathrm{L}$ maltose concentration. Similarly, maltotriose concentration in all four starch varieties at the end of the fermentation was below $5 \mathrm{~g} / \mathrm{L}$. Concentration of DP4+ at the beginning of SSF was observed to be about $250 \mathrm{~g} / \mathrm{L}$ for all starches except high amylose corn starch, where the starting concentration was $184 \mathrm{~g} / \mathrm{L}$. However, the concentration of DP4+ at the end of fermentation was less than $1 \mathrm{~g} / \mathrm{L}$ for all starches. 
Table 3. Concentrations of other sugars in conventional process.

\begin{tabular}{ccccccccccccc}
\hline Time (hours) & \multicolumn{4}{c}{ Maltotriose (g/L) } & \multicolumn{4}{c}{ Maltose (g/L) } & \multicolumn{4}{c}{ Glycerol (g/L) } \\
\hline & DCS & WCS & HACS & CS & DCS & WCS & HASC & CS & DCS & WCS & HACS & CS \\
\hline 0 & 30.2 & 22.08 & 33.94 & 29.11 & 32.36 & 28.67 & 0.00 & 31.89 & 0.00 & 0.00 & 0.00 & 0.00 \\
2 & 36.81 & 16.10 & 1.66 & 10.65 & 72.96 & 82.55 & 0.00 & 94.03 & 0.90 & 0.00 & 0.00 & 0.81 \\
4 & 21.8 & 2.96 & 0.57 & 2.98 & 90.93 & 85.22 & 0.00 & 93.50 & 1.96 & 0.00 & 1.98 & 1.75 \\
6 & 11.12 & 0.64 & 0.36 & 1.13 & 80.59 & 82.78 & 0.00 & 92.94 & 2.96 & 0.00 & 3.10 & 2.86 \\
8 & 9.305 & 0.36 & 0.27 & 0.56 & 96.27 & 76.32 & 0.00 & 86.50 & 3.93 & 0.00 & 3.5 & 4.00 \\
20 & 0.45 & 0.95 & 0.81 & 0.80 & 47.65 & 30.95 & 0.00 & 43.20 & 5.75 & 4.55 & 4.36 & 5.85 \\
24 & 0.68 & 1.42 & 0.00 & 1.09 & 35.64 & 19.59 & 0.00 & 30.23 & 6.08 & 4.62 & 4.56 & 5.99 \\
48 & 1.63 & 1.58 & 0.47 & 2.15 & 1.77 & 0.95 & 0.00 & 1.20 & 7.70 & 5.20 & 5.61 & 6.92 \\
72 & 0.51 & 0.35 & 0.31 & 0.40 & 0.85 & 0.00 & 0.00 & 0.42 & 8.02 & 5.30 & 5.84 & 7.12 \\
\hline
\end{tabular}

DCS: Dent Corn Starch; WCS: Waxy Corn Starch; HACS: High Amylose Corn Starch; CS: Cassava Starch.

\subsection{GSH Process}

The ethanol and glucose profiles for all four starches during GSH process are shown in Figure 6. Similar to the conventional process, the final ethanol concentrations for cassava starch $(127.9 \mathrm{~g} / \mathrm{L})$ with GSH process was similar to dent corn $(122.6 \mathrm{~g} / \mathrm{L})$ and waxy corn $(126.9 \mathrm{~g} / \mathrm{L})$. High amylose corn starch was found to yield lowest ethanol concentrations $(22.6 \mathrm{~g} / \mathrm{L})$, due to the inefficiency of enzymes to cleave the bonds of long polymeric chain of amylose. Similar final ethanol concentration for high amylose corn starch (17.3 g/L) were observed by Sharma et.al. [21]. The ethanol concentration for high amylose corn during GSH process was found to be about 79\% lower than that for conventional process. This can be attributed to the fact that the hydrolysis in this case was inefficient. Unlike conventional process, GSH process is carried out at low temperatures, which is not sufficient to break the hydrogen bonds. Since the enzymes need a certain length of amylose/amylopectin polymer to attach and cleave the bonds, the amylose in this case was inaccessible to the enzymes.

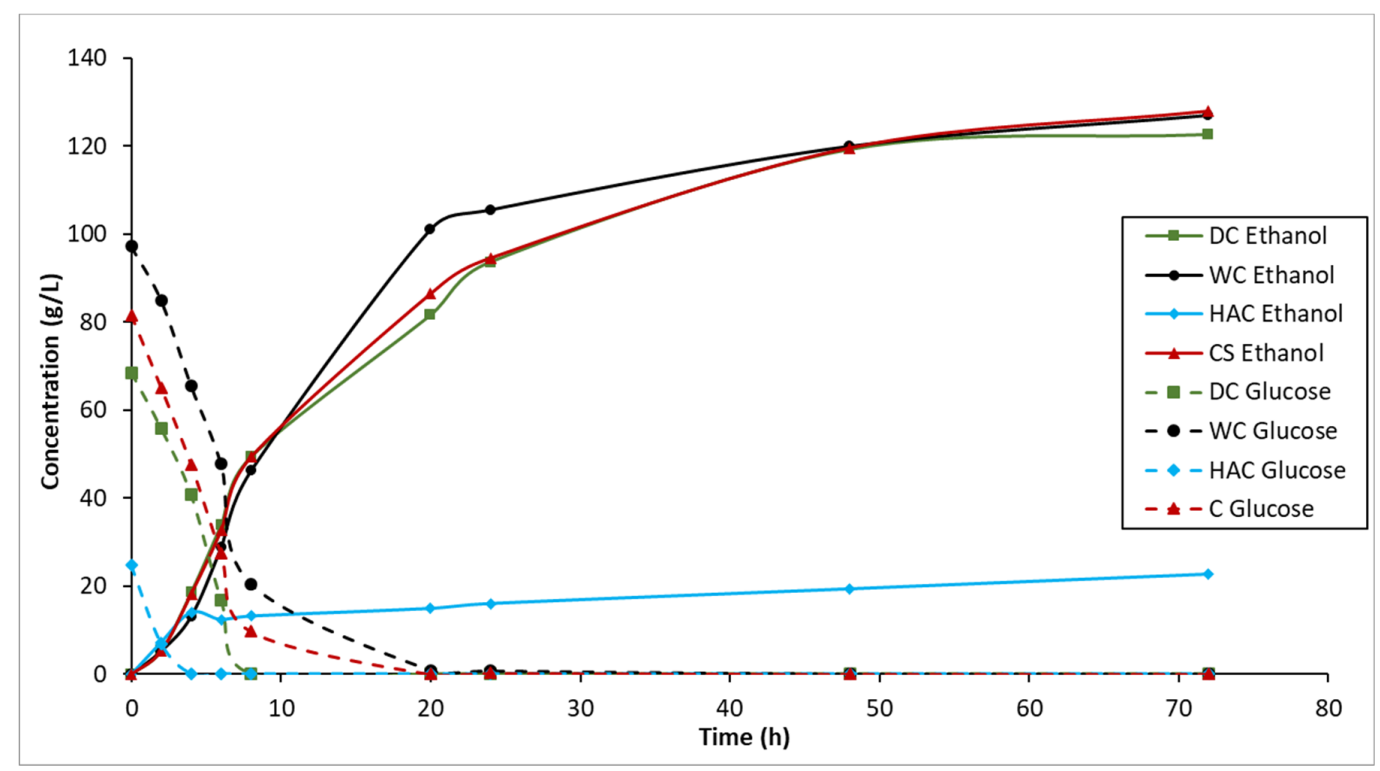

Figure 6. Comparison of ethanol and glucose profiles of dent corn (DC), waxy corn (WC), high amylose corn (HAC), and cassava starch (CS) during granular starch hydrolysis (GSH) fermentation (SSF at $30{ }^{\circ} \mathrm{C}$ for $72 \mathrm{~h}$ with GSH enzyme and yeast).

Statistically, the final ethanol concentrations for dent corn, waxy corn and cassava starch were similar. For cassava starch, the final ethanol concentrations with GSH process was $2.8 \%$ higher than that from conventional process, which suggests that with this starch source, the GSH process can be used to obtain higher ethanol yields. GSH process occurs at lower temperatures than conventional 
process, and eliminates the liquefaction step, thereby reducing the energy and cost for bioethanol production, which can be an added benefit for using GSH process for bioethanol production from cassava. In the current study, the final ethanol concentration with cassava starch $(127.9 \mathrm{~g} / \mathrm{L})$ was higher than previously reported in literature $[8,19]$.

In the case of the GSH process, the initial $8 \mathrm{~h}$ of fermentation had a linear trend of ethanol production with time for all starches, except high amylose corn starch (Figure $4 \mathrm{~b}$ ). This could be attributed to the fact that no glucose was detected after $4 \mathrm{~h}$ in this case, and subsequently, no ethanol change was observed. High amylose corn starch, therefore had the lowest fermentation rate (Table 2). Similar to conventional process, cassava had the highest initial fermentation rates, which were statistically similar to that of dent corn.

In contrast to conventional process, higher sugars such as maltose, maltotriose and DP4+ were negligible in case of GSH process, due to simultaneous consumption of these sugars. Glycerol production, however, was observed in GSH process (Figure 7). Concentration of glycerol at the end of the fermentation was highest and statistically similar for waxy corn and cassava. High amylose corn starch produced lowest glycerol, primarily because of incomplete hydrolysis and reduced amounts of sugars released for yeast consumption. With inadequate yeast growth due to lack of substrate, glycerol production is reduced [24].

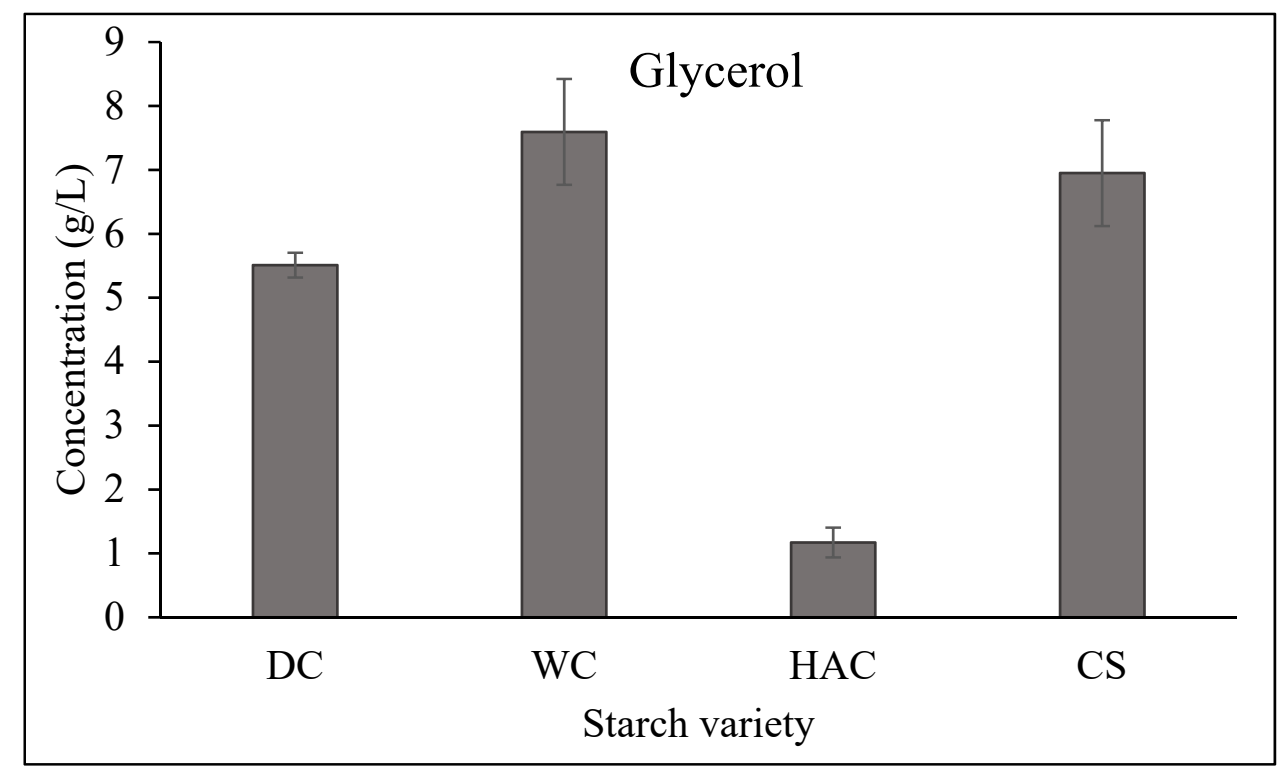

Figure 7. Final concentration of glycerol with four starch varieties (dent corn (DC), waxy corn (WC), high amylose corn (HAC), and cassava starch (CS)) for GSH (granular starch hydrolysis) process.

\section{Conclusions}

This study investigated the bioethanol production potential of cassava in comparison with the most widely used bioethanol substrate, corn. Both conventional and GSH process were used to evaluate the fermentation profile of cassava starch along with three corn varieties with varying amylose: amylopectin ratio. The final ethanol concentration with cassava starch was similar to two corn starch varieties, dent corn and waxy corn starch, for both conventional and GSH process. Ethanol concentration with cassava starch for GSH process was $2.8 \%$ higher than that for conventional process. For both conventional and GSH process, the fermentation rate for the initial $8 \mathrm{~h}$ of conventional process fermentation was higher for cassava starch than any of the corn starch varieties. Overall, the fermentation profile of cassava starch, in terms of ethanol production and formation of glycerol, was similar to that of dent corn and waxy corn starch, which suggests the potential of cassava starch use for commercial production of bioethanol. 
Author Contributions: S.P. carried out all the experiments, M.B.S. helped design the experiments, A.J. analyzed the results and wrote the manuscript, A.N. and V.S. supervised the study, VS. edited the manuscript. All authors read and approved the final manuscript.

Funding: This research was funded by a grant from National Institute of Food and Agriculture (NIFA) as a part of the NIFA (Hatch) Project No. ILLU-741-325- “Processing Corn and Cellulosic Biomass for Food, Fuel and Industrial Products".

Conflicts of Interest: The authors declare no conflict of interest.

\section{References}

1. Renewable Fuel Association. Ethanol Industry Outlook. 2017. Available online: http:/ www.ethanolrfa. org/resources/industry/statistics/\#1454098996479-8715d404-e546 (accessed on 16 June 2018).

2. Olguin-Maciel, E.; Larqué-Saavedra, A.; Pérez-Brito, D.; Barahona-Pérez, L.F.; Alzate-Gaviria, L.; Toledano-Thompson, T.; Lappe-Oliveras, P.E.; Huchin-Poot, E.G.; Tapia-Tussell, R. Brosimum Alicastrum as a Novel Starch Source for Bioethanol Production. Energies 2017, 10, 1574. [CrossRef]

3. Woiciechowski, A.L.; Medeiros, A.B.P.; Rodrigues, C.; de Souza Vandenberghe, L.P.; de Andrade Tanobe, V.O.; Dall'Agnol, A.; Gazzoni, D.L.; Soccol, C.R. Feedstocks for Biofuels. In Green Fuels Technology; Soccol, C.R., Brar, S.K., Faulds, C., Ramos, L.P., Eds.; Springer International Publishing: AG, Switzerland, 2016; pp. 15-39.

4. Okudoh, V.; Trois, C.; Workneh, T.; Schmidt, S. The potential of cassava biomass and applicable technologies for sustainable biogas production in South Africa: A review. Renew. Sustain. Energy Rev. 2014, 39, 1035-1052. [CrossRef]

5. Sebayang, A.H.; Hassan, M.H.; Ong, H.C.; Dharma, S.; Silitonga, A.S.; Kusumo, F.; Mahlia, T.M.I.; Bahar, A.H. Optimization of Reducing Sugar Production from Manihot glaziovii Starch Using Response Surface Methodology. Energies 2017, 10, 35. [CrossRef]

6. Moshi, A.P.; Hosea, K.M.; Elisante, E.; Mamo, G.; Mattiasson, B. High temperature simultaneous saccharification and fermentation of starch from inedible wild cassava (Manihot glaziovii) to bioethanol using Caloramator boliviensis. Bioresource Technol. 2015, 180, 128-136. [CrossRef] [PubMed]

7. Pervez, S.; Aman, A.; Iqbal, S.; Siddiqui, N.N.; Qader, S.A.U. Saccharification and liquefaction of cassava starch: An alternative source for the production of bioethanol using amylolytic enzymes by double fermentation process. BMC Biotechnol. 2014, 14, 49. [CrossRef] [PubMed]

8. Reddy, O.V.S.; Basappa, S. Direct fermentation of cassava starch to ethanol by mixed cultures of Endomycopsis fibuligera and Zymomonas mobilis: Synergism and limitations. Biotechnol. Lett. 1996, 18, 1315-1318. [CrossRef]

9. Ueda, S.; Zenin, C.T.; Monteiro, D.A.; Park, Y.K. Production of ethanol from raw cassava starch by a nonconventional fermentation method. Biotechnol. Bioeng. 1981, 23, 291-299. [CrossRef]

10. Kurambhatti, C.V.; Kumar, D.; Rausch, K.D.; Tumbleson, M.E.; Singh, V. Ethanol production from corn fiber separated after liquefaction in the dry grind process. Energies 2018, 11, 2921. [CrossRef]

11. Sriroth, K.; Wanlapatit, S.; Piyachomkwan, K. Cassava bioethanol. In Bioethanol; Lima, M.A.P., Ed.; InTechOpen Publishing: London, UK, 2012; pp. 3-32.

12. Wang, W. Cassava production for industrial utilization in China-present and future perspective. In Proceedings of the Cassava research and development in Asia: Exploring New Opportunities for an Ancient Crop: Seventh Regional Cassava Workshop, Bangkok, Thailand, 28 October-1 November 2002; pp. 33-38.

13. Khamkeaw, A.; Phisalaphong, M. Hydrolysis of cassava starch by co-immobilized multi-microorganisms of Loog-Pang (Thai rice cake starter) for ethanol fermentation. Food Sci. Biotechnol. 2016, 25, 502-516. [CrossRef] [PubMed]

14. Yuangsaard, N.; Yongmanitchai, W.; Yamada, M.; Limtong, S. Selection and characterization of a newly isolated thermotolerant Pichia kudriavzevii strain for ethanol production at high temperature from cassava starch hydrolysate. Antonie Van Leeuwenhoek 2013, 103, 577-588. [CrossRef] [PubMed]

15. Eliasson, A.C. Starch in Food: Structure, Function and Applications; Woodhead Publishing Limited: Oxford, UK, 2004.

16. Wu, X.; Zhao, R.; Wang, D.; Bean, S.; Seib, P.; Tuinstra, M.; Campbell, M.; O’brien, A. Effects of amylose, corn protein, and corn fiber contents on production of ethanol from starch-rich media. Cereal Chem. 2006, 83, 569-575. [CrossRef] 
17. Breuninger, W.F.; Piyachomkwan, K.; Sriroth, K. Tapioca/cassava starch: Production and use. In Starch, 3rd ed.; Elsevier: Amsterdam, The Netherlands, 2009; pp. 541-568.

18. Sharma, V.; Rausch, K.D.; Graeber, J.V.; Schmidt, S.J.; Buriak, P.; Tumbleson, M.; Singh, V. Effect of resistant starch on hydrolysis and fermentation of corn starch for ethanol. Appl. Biochem. Biotechnol. 2010, 160, 800-811. [CrossRef] [PubMed]

19. Wang, P.; Singh, V.; Xue, H.; Johnston, D.B.; Rausch, K.D.; Tumbleson, M.E. Comparison of raw starch hydrolyzing enzyme with conventional liquefaction and saccharification enzymes in dry-grind corn processing. Cereal Chem. 2007, 84, 10-14. [CrossRef]

20. Kumar, D.; Moy, K.; Singh, V. Ethanol yield calculation method-“an unaccounted factor” responsible for yield variations. In Proceedings of the 2017 ASABE Annual International Meeting, Spokane, WA, USA, 16-19 July 2017; American Society of Agricultural and Biological Engineers: St. Joseph, MI, USA; p. 1701287.

21. Sharma, V.; Rausch, K.D.; Tumbleson, M.E.; Singh, V. Comparison between granular starch hydrolyzing enzyme and conventional enzymes for ethanol production from maize starch with different amylose: Amylopectin ratios. Starch-Stärke 2007, 59, 549-556. [CrossRef]

22. Sriroth, K.; Piyachomkwan, K.; Wanlapatit, S.; Nivitchanyong, S. The promise of a technology revolution in cassava bioethanol: From Thai practice to the world practice. Fuel 2010, 89, 1333-1338. [CrossRef]

23. Juneja, A.; Kumar, D.; Singh, V. Germ soak water as nutrient source to improve fermentation of corn grits from modified corn dry grind process. Bioresour. Bioprocess. 2017, 4, 38. [CrossRef] [PubMed]

24. Nordström, K. Yeast growth and glycerol formation. Acta Chem. Scand. 1966, 20, 1016-1025. [CrossRef] [PubMed]

(C) 2018 by the authors. Licensee MDPI, Basel, Switzerland. This article is an open access article distributed under the terms and conditions of the Creative Commons Attribution (CC BY) license (http:/ / creativecommons.org/licenses/by/4.0/). 